\title{
LESSONS LEARNED BY MOVING TOWARDS OPEN, FREE AND SELF-PACED ONLINE RESOURCES IN HIGHER EDUCATION.
}

\author{
Mark Stenersen ${ }^{1}$, Jelena Larsen ${ }^{2}$ \\ ${ }^{1}$ UIT-The Arctic University of Tromsø (Norway) \\ ${ }^{2}$ UIT-The Arctic University of Tromsø (Norway)
}

\begin{abstract}
In an ever changing and rapidly developing teaching situation, it is often difficult to keep oneself updated with all types of available technologies. The "wants" are often centre of attention and the how's and why's become neglected and are subject to hindsight. In a 2008 report (Economist 2008) [1] the question: "what does it mean to be an educated person in the $21^{\text {st }}$ century", was raised and concluded with the importance of keeping up with technology - as these changes in the use of technology, at a higher education level, will have a ripple effect on the future society as a whole.
\end{abstract}

In the last 10 to 15 years, higher education (HE) institutions in Norway have invested heavily in information and communication technologies (ICT), which has had a major impact on our own organization, UiT - The Arctic University of Norway; as in to say that it has brought with it some changes to our methods of teaching, and hopefully, it will keep thrusting us towards a better understanding of how to convey best practices and use of ICT in our teaching environments. The role of technology therefore is in shaping the future of higher education. It will, no doubt, have a profound impact on the way we work towards helping our staff to become comfortable with and interested in using technology in and throughout their teachings.

However, taking the leap and diving into new and sometimes advanced technologies can raise feelings of uncertainty in one's own technical abilities, especially for those with limited technical competencies. Combined with the need to find a good balance between hands-on skills and didactical competence, and finding the time necessary [2][3], outside an organized framing of a physical course, can be a real challenge to many.

Keywords: Educating the Educators, Flipped Learning, Training educational staff, online resources

\section{IT IS ALL ABOUT PEDAGOGY AND KNOWING HOW AND WHEN TO APPLY TECHNOLOGY}

As pointed out in UiT's newly published strategy (UiT 2020 - Developing High North) [4] we need to focus on some key points in regards to how we view our own approach. Essential to any understanding is getting to grips with the fact that we need to increase our use of web-based teaching in order to make programs accessible off campus as well as available to all our satellite campuses. In light of this, we also need to appreciate that our educators should be able to use ICT tools that contributes to more student-centered teaching.

With that in mind, we always need to look at our reasons for using technology. Using it for the sake of using technology must not become the standard as it takes our focus away from what is really important - the quality of teaching. Technology should give us better focus on learning and not so much on process. Therefore, educators' skills in the use of ICT emerges as paramount to any teaching situation, and we must ensure that educators acquire the necessary skills within pedagogy and ICT to be able to handle technology as a part of their teaching. 


\title{
2 RESULT AS AN INTERMEDIATE BETWEEN FACILITATOR AND USER
}

Result's (Centre for Teaching, Learning and Technology) is a relatively small organisation within the Northern University of Norway, UiT. We are approximately 23 people altogether, where half of us are working directly with ICT in education. We are in direct contact with university administrative and faculty staff, helping them develop methods and technical skills and tools for them to use in their own work/teaching. In addition, we are active participants in projects where we develop and test new tools and methods, trying to enhance, and spread knowledge about use of ICT in education from a pedagogical point of view.

As an organization we therefore want to establish a connection between technology and pedagogically use of technology, and this positions us as a bridge between the universities IT department and those who use technology - the teachers. So Results foremost objective is to help university staff and educators to work with, and effectively use, technology, and in doing so work out an effective strategy for multi-modal teaching. All within the scope of contributing to UiT's ability to reach its strategical goals as outlined in the Strategy 2020 document.

\section{APPROACH}

In order to work towards UiT 2020, we needed to make some changes to our way of working. Therefore, our first approach was to try to define the exact needs in order to help our staff. A precursor to this were the multitude of face-to-face courses we held. These were always popular, and almost every course offered was fully booked. What, we in years of doing it this way, found was that our staff had far less problems signing up for a course - than actually taking the courses. Time, it seemed, was the culprit more often than not. Our staff, just could not find time in their already busy schedule to take our courses, and therefore did not attend. So our very positive sign-ups often transformed into failed attendances.

In 2012 we decided to offer our knowledge a different way. We called it "Handboka" - The Handbook. This was going to be an online resource open and available to everyone, outlining all our technological and pedagogical knowledge in one easy to find and easy to use resource. We divided it into three levels.

\author{
- Basic introduction to technology (search for) \\ - A more in depth discussion one how to use said technology with emphasis on \\ pedagogical methods. \\ - Deep and research-based insights into said technology.
}

This was a massive undertaking for a small group like ours, but we were very optimistic, and hoped for massive success for our new "product". All efforts were made to create something useful for our educators and at the same time create something that would map our own entire knowledge base; it was evident that we had no internal overview of how much we as a group actually knew. In this sense The Handbook was just as much a way for us to organize ourselves as to be able to point educators' questions in the direction of the right resource.

The most important insight from this entire process was the same as our teachers and staff already had met in signing up for our face-to-face courses - we just could not find the time to write, design and publish all this knowledge. Trying to set aside time and resources in addition to everything else, was not going to happen, and the project suffered fatally from this. The Handbook fell into disrepair and never even got as far as being launched. Being an active first-line-support for all practical EdTech (Educational technology) use on campus, including having fulltime teaching of the course for Basic pedagogical competence for higher education, we just did not have time to set aside to manage this project. We had to come up with another plan.

Therefore, in 2015, Result started working on uDig (Abbv.), a self-paced, Open Learning Resource specifically aimed at our university teaching staff, with the aim of introducing them to existing, as well as emerging, technologies available to them. uDig contained four modules to start with:

1. Digital tools in Fronter (LMS),

2. Using video in teaching,

3. Online discussions and collaboration,

4. Flipped classroom and student response systems (SRS). 
In conjunction with the online resource, Result also offered workshops where teachers and staff could get a more hands-on introduction to systems and technologies discussed in uDig as a whole. In this way we hoped to lessen initial trepidation in use of technology, and putting more emphasis on the why's and how's rather than the actual practical skills needed.

The crucial difference in this second attempt was that we made four teams - one for each module, and we decided to work on questions we most often met. In addition, we made sure that we set aside time in our official calendar to work with both design and content, and chose to use a platform that did not offer us too many problems in the sense that it worked more or less out of the box.

Spanning some six months we managed to write, record videos and make demos and tests that would cater for the most frequently asked questions. In addition, we were also able to offer special insights into new ways of working with methods like flipped classroom, studio recording of videos etc.

We had only one failure - if we can call it that. In conjunction with the content offered, we decided to organize face-to-face workshops, where our educators could come and get first-hand experience with some of the tools, and methods outlined in uDig. This though, suffered from the same problem faced in the first place. Sign-up was high, but attendance was too low to justify our efforts. So far, we have not organized any new workshops, but rather have decided to offer tailor-made workshops when required or asked for.

\section{FUTURE OF UDIG}

Taking everything into account we have to be very satisfied with our results. We have not been able to introduce everyone to uDig. We assume this is more a problem of marketing, than a problem with the product. We have therefore a program in the workings to spread our online resource to all staff at all campuses more effectively.

More importantly, we see a definite future for uDig. We are considering ways of creating workshops that work better in busy work schedules. We are also looking at possibilities to add more interactive content; feedback from other online courses we have made have often included a desire for more tests and simple assignments.

We are also looking to renew our initial design in order to meet the direct needs of our educators, such as adding search and find possibilities based on keywords and content in general.

\section{CONCLUSION}

Summing up our experience going through multiple ways of creating a useful online resource for educators and university staff in general. We feel that we are looking at something that will not so much change the way we work, but more importantly open our eyes for new ways and ideas on how to work in a demanding work environment.

An internal evaluation report [5] revealed that our initial assumption, creating an online, open and selfpaced resource would help our staff in considering the use of, and learning more about technology was indeed correct. To build on these lessons we have consequently developed two new modules in uDig: learning strategies and introduction to digital surfaces, and also started work on a seventh module about using MOOCs as a teaching strategy.

According to the report, uDig, has since its release, been well received by all educators at our university, and it keeps gathering attention from the whole of Norway. We like to see it as a success in every way, indicating to us the importance of the work and that the idea was a good one in the first place. We are eager to continue the work on uDig in order to meet the strategic goals set in UiT 2020.

Following that, Result, will still keep an eye on what is happening in the world of EdTech, and keep working as an ICT-Lab, where actual results from research as well fully integrated and working solutions inform and inspire us to keep planning, developing and launching online open resources, such as uDig.

\section{REFERENCES}

[1] The future of higher education: How technology will shape learning, The Economist Int. Unit. Retrieved from: http://www.nmc.org/pdf/Future-of-Higher-Ed-(NMC).pdf 
[2] Dysthe, O. (2001). Dialogperspektiv på elektroniske diskusjonar. I O. Dysthe (red.), Dialog, samspel og læring (vol. 2001, pp. 309-347). Oslo: Abstrakt forlag.

[3] Dyste, O., \& Igland, M.-a. (2001). Michail Bakhtin og sosiokulturell teori. O. O. Dyste (red.), Dialog, samspel og læring. Oslo: Abtract forlag.

[4] Strategic plan for UIT the Arctic University of Norway 2014-2020: https://en.uit.no/om/art?p_document_id=377752\&dim=179033\#sthash.vPFHCpWp.dpuf

[5] uDig Rapport (2015), Erfaringer, analyser og tanker om veien videre. Unpublished report Result, UiT - The Arctic University of Norway. Retrieved from: https://result.uit.no/wpcontent/uploads/2016/03/Rapport-uDig_Erfaringer-analyser-og-tanker-om-veien-videre.pdf 


\section{Educating the educators}

Lessons learned by moving towards open, free and selfpaced online resources in higher education (HE).

\section{EDULEARN16 July 4th}

Presented by Jelena Larsen \& Mark Stenersen

Result | Center for Teaching, Learning and Technology 


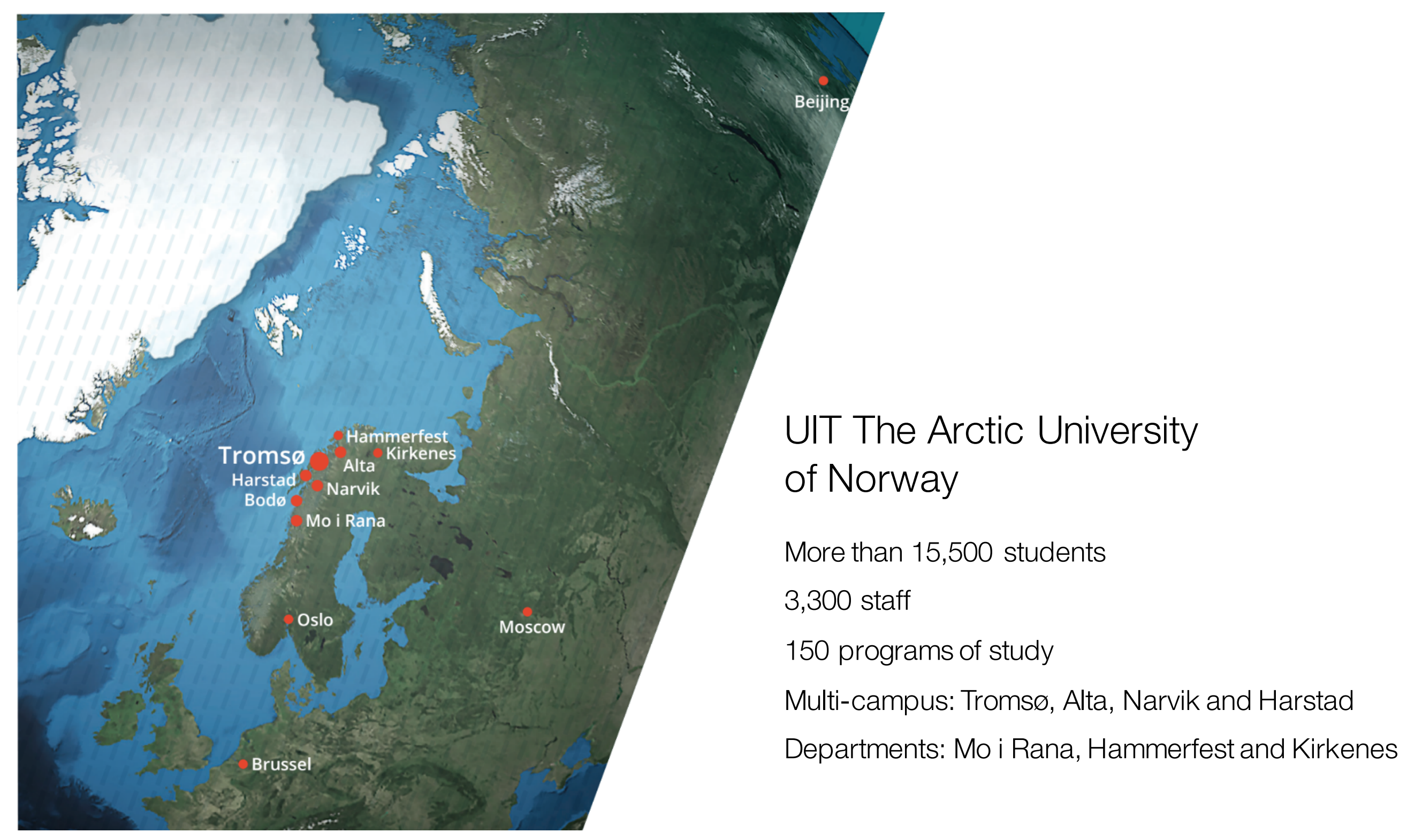




\section{UIT STRATEGY}

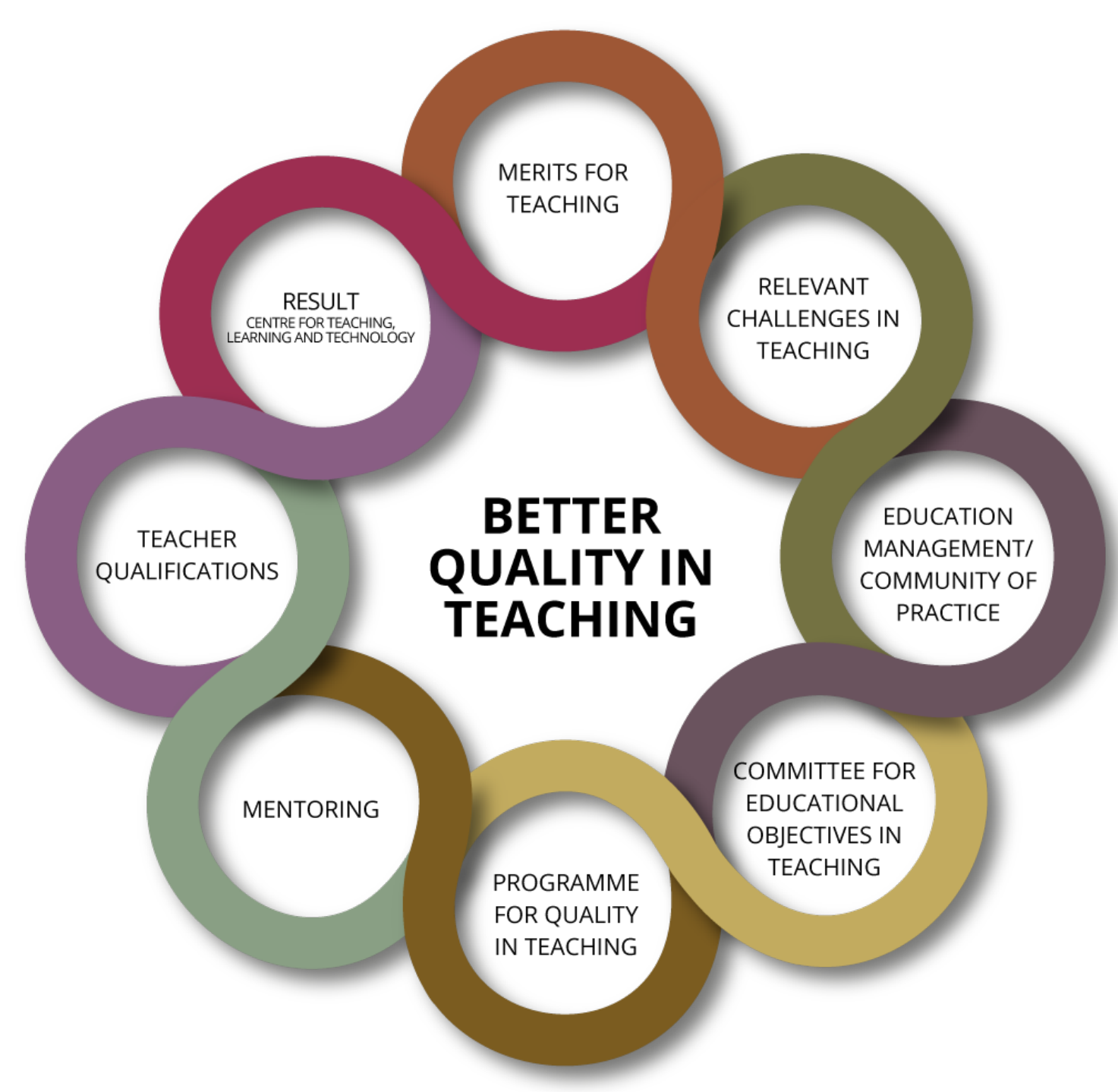


It's all about pedagogy 


\section{It's all about pedagogy}

Increase the use of web-based teaching

- Availability of education off- and satellite campuses

- Use of ICT tools that contributes to more student-centered teaching

Fokus on learning and not so much on prosess

Required skills whithin pedagogy and ICT to be able to handle technology as a part of their teaching. 


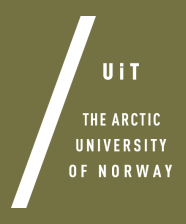

Approach 


\section{Approach}

\section{Face to face courses}

\section{Handbook - easy to find and easy to use resource}

- Basic introduction to technology (search for)

- More in-depth: how to use technology with empasis on pedagogical methods

- Research-based insights

\section{uDig: self-paced Open Learning Resource}

- Digital tools in Fronter (LMS)

- Using video in teaching

- Online discussions and collaboration

- Flipped classroom and student respons systems (SRS) 


\section{uDig, in numbers}

Since february 2015

\begin{tabular}{|c|c|c|}
\hline $\begin{array}{l}\text { Sessions } \\
3,182\end{array}$ & 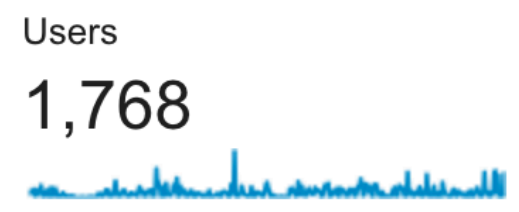 & $\begin{array}{l}\text { Page Views } \\
14,880\end{array}$ \\
\hline
\end{tabular}

\begin{tabular}{|c|c|}
\hline $\begin{array}{l}\text { Pages/Session } \\
4.68\end{array}$ & $\begin{array}{l}\text { Avg. Session Duration } \\
00: 05: 03\end{array}$ \\
\hline
\end{tabular}




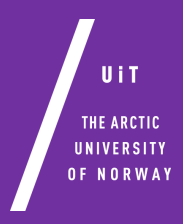

uDig - future 


\section{uDig - future}

Customised workshops

Add more iteractive content to $\mathrm{UDIG}$

Renewing design

Marketing 


\section{Conclusion}

- uDIG is usefull on-line resource

- Well received by all educators Norway(according to evaluation report)

- Attention from whole Norway

- Continue the work on UDIG in order to meet strategic goals set in UiT2020 
Thank you for your attention

Jelena Larsn \& Mark Stenersen 